\title{
Phytoplankton photosynthesis, productivity, and species composition in a eutrophic estuary: comparison of bloom and non-bloom assemblages
}

\author{
Charles L. Gallegos \\ Smithsonian Environmental Research Center, PO Box 28, Edgewater, Maryland 21037, USA
}

\begin{abstract}
During 2 periods in the late spring and early summer 1989, blooms in the Rhode River Maryland, USA, were triggered by nutrient inputs from local and remote watersheds. Parameters of the photosynthesis-irradiance relationship increased in May when the bloom was dominated by Thalassiosira pseudonana, and decreased in June when the bloom was dominated by large dinoflagellates. Relative variability of quantum efficiency was as great as that of chlorophyll-specific absorption coefficient. Light-saturated photosynthetic rates were predictable based on species counts and previously published size-dependent, nutrient-saturated growth rates for diatoms and dinoflagellates. Dinoflagellate blooms occur in years of high hydrologic nutrient input, but, due to the reduced photosynthetic efficiency of the dinoflagellate blooms, carbon fixation in the system varies proportionately less than biomass.
\end{abstract}

\section{INTRODUCTION}

Since the possibility of estimating phytoplankton productivity from light and pigment data was first suggested by Ryther \& Yentsch (1957), considerable research has been devoted to attempting to understand factors governing the variability in pigment-specific parameters of the photosynthesis-irradiance relationship (i.e. P-I parameters) (Harrison \& Platt 1980, 1986, Falkowski 1981). Interest in estimation of productivity from light and chlorophyll, which was originally conceived as a substitute for the time-consuming incubations necessary to estimate phytoplankton productivity directly, has been renewed recently by the widespread availability of near-surface pigment data from satellite remote sensing (Platt \& Sathyendranath 1988). Presently, the most sophisticated remote sensing algorithms (Sathyendranath \& Platt 1989) combine regionally (and potentially seasonally) cataloged spectral photosynthesis-irradiance (P-I) parameters with the underwater light spectrum to calculate the depthintegral of phytoplankton production.

Discussions of factors governing P-I parameters typically include species composition, usually by associating a posteriori particular episodes of high or low parameters with dominance by certain species (Harrison \&
Platt 1980, Côte \& Platt, 1983, Sephton \& Harris 1984). In contrast to factors such as light and temperature, the role of species composition has received little quantitative treatment, because determination of photosynthetic rates of individual species in mixed field assemblages is a difficult task. In some cases, when densities of large, robust cells are high, photosynthetic rates of individual cells can be determined by micropipetting (Rivkin \& Seliger 1981, Boulding \& Platt 1986), but this generally cannot be done with small or delicate species.

Recently, Joint \& Pomroy (1988) used an allometric approach to estimate the volumetric rate of productivity (i.e. not normalized to pigment concentration) at optimum depth. They used microscopic analyses of samples and the phylum- and size-dependent growth equations of Banse (1982) to estimate the maximal rate of carbon increase. Here I extend their analysis to predict the chlorophyll-specific light-saturated photosynthetic rate, $P_{\mathrm{m}} \mathrm{B}$, from estimates of species abundances. To do so I combine the allometric growth equations of Banse (1982) with recent models relating photosynthetic parameters to growth rate (Geider et al. 1986, Sakshaug et al. 1989, Cullen 1990).

Phytoplankton blooms in estuaries are frequently dominated by one or a few species, are ephemeral in 
nature, and are often patchy in space (Paerl 1988). The marked changes in species composition over short times or distances associated with phytoplankton blooms afford an opportunity to examine the relationship between species composition and photosynthetic parameters in greater isolation from other factors than can generally be achieved in a seasonal or synoptic study In 1989, 2 rany periods during the spring and early summer resulted in elevated nutnent inputs and unusually high chlorophyll concentrations in the Rhode River, a small tributary embayment of Chesapeake Bay, USA. Gallegos et al. (1992) demonstrated that nutrient inputs from the local watershed produced localized blooms of short duration in the upper subestuary, which were followed about 2 wk later by blooms throughout the sub-estuary resulting from nutrient inputs from the delayed arrival of the freshet down the mainstem of Chesapeake Bay Here I report species composition and photosynthetic parameters of the blooms, and their effect on estumates of depthintegrated productivity. For each event, I first present the response of the upper estuary to inputs from the local watershed, and then the response of the lower sub-estuary to the salınity drop at the mouth of the Rhode Ruver I then examine the predictions of the allometnc relationships for selected penods when photosynthetic parameters varied considerably over short times or distances.

\section{MATERIALS AND METHODS}

Study site. The Rhode River sub-estuary $\left(38^{\circ} 52\right.$ 'N, $76^{\circ} 32^{\prime}$ W; Fig. 1) is one of several tributary embay-

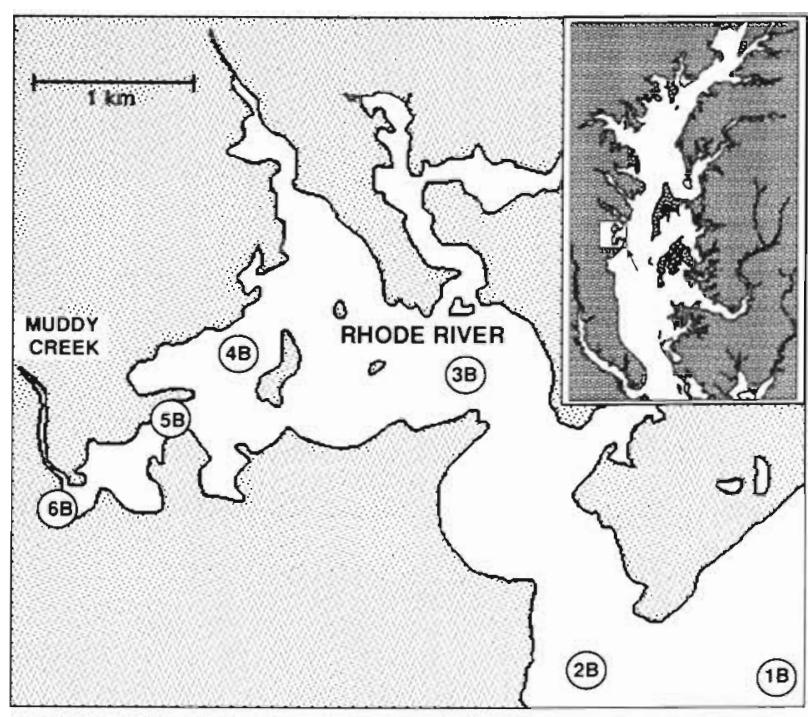

Fig 1 Rhode River showing station locations Inset shows location of Rhode River on Chesapeake Bay in Maryland (USA) ments on the western shore of Chesapeake Bay, Maryland, USA. It is 550 ha in area and averages $2 \mathrm{~m}$ deep, with a maximum of $4 \mathrm{~m}$. The mean tidal range is $30 \mathrm{~cm}$, but weather conditions often cause more extreme changes in water level. Salinity varies seasonally from 0 ppt in spring at the head of Muddy Creek, the principal freshwater inflow to the Rhode River, to almost 20 ppt at the mouth in fall during years with low runoff.

Nutrient concentrations in the Rhode River are generally high (Jordan et al. 1991). Phosphate concentrations typically peak in the summer at about $5 \mu \mathrm{M}$; ammonum is always present and concentrations are relatıvely constant, averaging about $4 \mu \mathrm{M}$. Nitrate typically becomes undetectable in mid May (Jordan et al. 1991); 1989 was unusual in that several late spring and early summer storms increased $\mathrm{NO}_{3}{ }^{-}$loading both from the local watershed and from the Susquehanna River, the principal freshwater source to the upper Chesapeake Bay. The increased $\mathrm{NO}_{3}{ }^{-}$loading caused phytoplankton blooms that produced chlorophyll concentrations well above the seasonal mean of $50 \mu^{g^{-1}}$ (Gallegos et al. 1992). Procedures for calculating $\mathrm{NO}_{3}{ }^{-}$ loading from the Muddy Creek watershed are given by Gallegos et al. (1992).

Field sampling and experimental methods. Samples for phytoplankton chlorophyll, species composition, and photosynthesis-irradiance curves were collected along a transect of 6 stations from $1.4 \mathrm{~km}$ downstream to $5.5 \mathrm{~km}$ upstream of the mouth of the Rhode River (Fig. 1). The most upstream station was dominated by advective flow due to the high runoff during the period of interest, and will not be reported. Samples were taken from the Secchi depth using a 21 Labline Teflon sampler, emptied unto 21 polyethylene containers while being shielded from direct sunlight, and returned to the laboratory in a cooler. Cruises were generally conducted weekly; samples were taken daily during a $7 \mathrm{~d}$ penod following a large storm in July 1989. Station numbering follows that of Gallegos et al. (1992); the 'B' following station numbers designates 'bottle cast' to distinguish them from transect samples taken by pump as part of a water quality monitoring program (not reported here)

Vertical profiles of temperature and salinity were made using a Beckman RS5-3 induction salinometer. Vertical profiles of in vivo fluorescence were measured using a Turner Desıgns model 10-005R fluorometer. Underwater quantum scalar irradiance $(400$ to $700 \mathrm{~nm})$ was measured using a Biospherical Instruments QSP-170 $4 \pi$ collector and QSR-250 integrator. Diffuse attenuation coefficients for quantum scalar irradiance were calculated from regression of log-transformed readings against depth. Secchi depth was measured with a $20 \mathrm{~cm}$ solıd white disk. 
Subsamples for species identification were preserved immediately in the field using $1 \%$ acid Lugol's solution and stored in $125 \mathrm{ml}$ polyethylene bottles kept in the dark until counting ( 6 to $8 \mathrm{mo}$ ). For counting, 1 to $10 \mathrm{ml}$ were settled (minimum $4 \mathrm{~h}$ ) and viewed at a magnification of $512 \times$ under an inverted microscope. Abundant taxa were estimated from the number of fields required to count 200 individuals; density estimates of less abundant taxa were based on the number of individuals in 20 fields. Taxa comprising $<10^{2}$ cells $\mathrm{ml}^{-1}$ are recorded as 'present'. All cells were identified to the lowest taxonomic grouping possible, which was nearly always genus or lower.

Cellular carbon contents were estimated from cell volume (or plasma volume for diatoms) using the relations of Strathman (1967). Volumes were estimated by assigning the taxa to regular geometric solids and applying mensuration formulae using appropriate linear dimensions determined from diagrams and descriptions in keys or, in some cases, from measurements on specimens from this site.

Subsamples for chlorophyll analyses were filtered onto Whatman GF/F glass fiber filters immediately upon return to the laboratory. Filters were extracted in $10 \mathrm{ml}$ of $90 \%$ acetone overnight at $4{ }^{\circ} \mathrm{C}$ either immediately or after freezing for $<2 \mathrm{wk}$. Extracted chlorophyll was estimated fluorometrically using a Gilson SpectraGlo fluorometer calibrated against chlorophyll a determined periodically using the spectrophotometric equations of Jeffrey \& Humphrey (1975).

Absorption spectra by particulate matter were determined with an EG \& G Gamma spectrometer interfaced to a LiCor 1800-12 integrating sphere (Gallegos et al. 1990). Water was filtered onto a $25 \mathrm{~mm}$ Whatman $\mathrm{GF} / \mathrm{F}$ filter and scanned at $2 \mathrm{~nm}$ intervals from 400 to $750 \mathrm{~nm}$. Filters were extracted overnight in methanol, then extracted a second time for $30 \mathrm{~min}$ before being rehydrated and scanned again to determine absorption by nonpigmented particulate material (Kishino et al. 1985).

Measured absorbances, after correcting for volume filtered and area of the filter, were divided by a pathlength amplification factor (Kiefer \& SooHoo 1982) of 1.8. This is lower than the pathlength amplification factor of 3.31 used by Gallegos et al. (1990), who kept filter loading low enough for absorption to be read at full scale of 0.5 absorption units. In this work I used heavier filter loading to minimize the wavelength dependence of the pathlength amplification factor that occurs at low absorbance (Mitchell \& Kiefer 1984, Bricaud \& Stramski 1990). Corrected absorbance of the depigmented filters was subtracted from that of the unextracted filters, and the difference was divided by the chlorophyll concentration to give the chlorophyllspecific absorption spectrum of the phytoplankton, $a^{*}{ }_{\mathrm{ph}}(\lambda)$, where $\lambda=$ wavelength (nm). Spectral mean absorption, $k_{\mathrm{c}}$ was then calculated as

$$
k_{c}=\frac{1}{(700-400)} \int_{400}^{700} \alpha_{p h} \cdot(\lambda) d \lambda
$$

Phytoplankton photosynthesis was measured as ${ }^{14} \mathrm{C}$ uptake using the 'photosynthetron' method of Lewis \& Smith (1983). A $50 \mathrm{ml}$ subsample was inocculated with 370 to $1850 \mathrm{kBq} \mathrm{NaH}{ }^{14} \mathrm{CO}_{3}$, depending on biomass as anticipated based on fluorescence profiles. Subsamples of $1 \mathrm{ml}$ were dispensed into 26 (24 lighted, 2 darkened) $7 \mathrm{ml}$ glass scintillation vials placed in an aluminum block bored with holes for lighting from below. Incubations were commenced within ca $2 \mathrm{~h}$ of sample collection and lasted $1 \mathrm{~h}$. A range of light intensities was supplied by a Westinghouse $400 \mathrm{~W}$ metal halide lamp. Incubations were terminated by acidifying the samples with $250 \mu \mathrm{l}$ of $6 \mathrm{~N} \mathrm{HCI}$ and shaking $1 \mathrm{~h}$ to drive off unincorporated ${ }^{14} \mathrm{C}$ (Lewis \& Smith 1983). Samples were then neutralized with $\mathrm{NaOH}$ and $5 \mathrm{ml}$ scintillation cocktail (Ecolume, Packard) was added. Rates of ${ }^{14} \mathrm{C}$ uptake were calculated by the equations of Strickland $\&$ Parsons (1972), using an isotope discrimination factor of 1.06 .

Light intensities (400 to $700 \mathrm{~nm}$ ) were measured at the termination of the incubations using a Licor LI-185B quantum radiometer and $2 \pi$ sensor inside a specially made adaptor that reproduces the geometry of the hole in the aluminum block and holds the sensor at the level of the sample meniscus. Comparisons of $\alpha^{B}$ measured in the photosynthetron with measurements made in polystyrene flasks, in which light intensity is more reliably measured, indicate that this procedure underestimates light actually available to the phytoplankton by a factor of 2.3, due most likely to a combination of internal reflections, focusing by the bottom of the vial, and placement of the detector too high (Gallegos unpubl.). Parameters dependent on light readings (especially $\alpha^{\mathrm{B}}$ but sometimes also a photoinhibition parameter, see below) were adjusted accordingly.

Data analysis. In the absence of photoinhibition, the P-I relationship was represented by the equation (Jassby \& Platt 1976)

$$
P^{\mathrm{B}}(\mathrm{I})=P_{\mathrm{m}}{ }^{\mathrm{B}} \tanh \left(\frac{\alpha^{\mathrm{B}} \mathrm{I}}{P_{\mathrm{m}}^{\mathrm{B}}}\right)+R^{\mathrm{B}}
$$

where the intercept, $R^{B}$ is allowed to be either positive or negative to avoid bias in calculation of $\alpha^{\mathrm{B}}$. When photoinhibition was observed I used the equation (Platt et al. 1980)

$$
P^{\mathrm{B}}(\mathrm{I})=P_{\mathrm{s}}^{\mathrm{B}}\left[1-\exp \left(\frac{-\alpha^{\mathrm{B}} \mathrm{I}}{P_{\mathrm{s}}^{\mathrm{B}}}\right)\right] \exp \left(\frac{-\beta \mathrm{I}}{P_{\mathrm{s}}^{\mathrm{B}}}\right)
$$

where $\beta$ controls the degree of photoinhibition in the fitted curve at high light intensities. Values of $\alpha^{B}$ esti- 
mated by Eq. (2) were divided by $1.20\{=\tanh (1) /$ $[1-\exp (-1)]\}$ to adjust for the tendency for the fitting routine to overestimate $\alpha^{\mathrm{B}}$ to compensate for the lack of a well defined linear range at low light intensities in Eq. (2). After correcting for underestimation of light intensities in the photosynthetron, photoinhibition was rarely significant at ambient light intensities.

Corrected values of $\alpha^{\mathrm{B}}$ and measured $k_{\mathrm{c}}$ were used to estimate quantum efficiency, $\phi$, by the relation

$$
\phi=0.0231 \frac{\alpha^{\mathrm{B}}}{k_{\mathrm{c}}}
$$

where the constant converts $\alpha^{B}$ to units of $\mu \mathrm{mol} \mathrm{C}$ (mg $\mathrm{chl})^{-1} \mathrm{~s}^{-1}$ (umol quanta $\left.\mathrm{m}^{-2} \mathrm{~s}^{-1}\right)^{-1}$.

For calculation of the depth-integral of production over the day, $\int p_{d}$, Eq. (1) or (2) and estimated parameters were used with measured chlorophyll concentrations, diffuse attenuation coefficients and hourly averages of incident sunlight reduced by $10 \%$ for surface reflection, to calculate photosynthesis as a function of depth and time; calculated photosynthetic rates were then integrated numerically. For standardization, integrations in the vertical direction were always carried out to the photic depth $(1 \%$ penetration), although it should be understood that in the upstream shallow regions, the photic depth sometimes exceeded the actual depth. Because the estimates are based on short term ( $1 \mathrm{~h})$ measurements and include any excreted fixed carbon, they represent values closer to gross daily photic zone production than to net production. Furthermore, chlorophyll concentrations were assumed to be uniform with depth, which is usually true in this shallow system; but during June-July 1989 , pronounced subsurface chlorophyll maxima were sometimes present at or near the sampling depth (see e.g. Table 5 in Gallegos et al. 1990). The calculated daily production estimates should therefore be regarded as potential rates for comparing bloom with pre-bloom conditions.

Photosynthetic parameters and species composition. I assumed all taxa present were growing at maximal rates. For diatoms and dinoflagellates I used the size- und phylum-dependent relationships of Banse (1982); he suggested that other microalgal taxa were intermediate between diatoms and dinoflagellates, so for those I used coefficients that were the median of the corresponding coefficients for diatoms and dinoflagellates. The allometric growth equations may be expressed (Banse 1982)

$$
u=a C^{b}
$$

where $\mu$ (base $e_{;} \mathrm{d}^{-1}$ ) $=$ light- and nutrient-saturated exponential growth rate $\mathrm{C}\left(\mathrm{pg} \mathrm{cell}^{-1}\right)=$ cellular car bon; and $a$ and $b$ are coefficients. For diatoms, $a=3.02$, $b=-0.13$; for dinoflagellates $a=1.38, b=-0.15$
(Banse 1982); for all others I used $a=2.20, b=-0.14$ (my interpolations).

The relationship of $P_{\mathrm{m}}{ }^{\mathrm{B}}$ to growth rate is given by a modification of the equation of Geider et al. (1986)

$$
\mu+r=p_{\mathrm{m}}{ }^{\mathrm{B}} D \theta^{-1}
$$

where $r\left(\mathrm{~d}^{-1}\right)=$ respiration rate; $D=\mathrm{h}$ of daylight; and $\theta=$ cellular $\mathrm{mg} \mathrm{C}(\mathrm{mg} \mathrm{chl})^{-1}$. Letting $r=0.15 \mu$ (i.e. energetic cost of synthesis slightly higher than respiratory $\mathrm{O}_{2}$ consumption; Geider et al. 1986), we can solve for $P_{\mathrm{m}}{ }^{\mathrm{B}}$ of the $j^{\text {th }}$ species

$$
P_{\mathrm{m}}^{\mathrm{B}}(j)=1.15 a(j) \mathrm{C}(j)^{b(j)} \theta D^{-1}
$$

For the mixed field assemblage, Eq. (5) is summed over the species present, weighting the contribution of each species by its cellular carbon. For $\theta$, I used a constant value of 40 , in spite of known taxonomic dependence (see 'Discussion'). Values estimated from field samples are highly variable, ranging from 4 to 120, and averaging about 30. A higher value was used because carbon estimates based on cell counts can be expected to be biased low due to omission of present but uncounted species.

\section{RESULTS}

\section{April to 10 June 1989}

Following a week of high nitrate loading from the local watershed of Muddy Creek in late April and early May 1989, chlorophyll concentration at Stn 5B in the upper sub-estuary bloomed from about 30 to $120 \mu \mathrm{g} \mathrm{l}^{-1}$ (Fig. 2A). The bloom consisted mainly of small phytoplankton; changes in chlorophyll concentration at Str $5 \mathrm{~B}$ generally paralleled changes in numerical abundance of the nanoplankton fraction (Fig. 2B).

Prior to the bloom, photosynthetic parameters, $P_{\mathrm{m}}{ }^{\mathrm{B}}$ and $\alpha^{B}$, averaged $3.7 \mathrm{mg} \mathrm{C}(\mathrm{mg} \mathrm{chl})^{-1} \mathrm{~h}^{-1}$ and $0.034 \mathrm{mg}$ $\mathrm{C}(\mathrm{mg} \mathrm{chl})^{-1} \mathrm{~h}^{-1}$ (umol quanta $\left.\mathrm{m}^{-2} \mathrm{~s}^{-1}\right)^{-1}$; Fig. 2C) respectively. Following the $\mathrm{NO}_{3}{ }^{-}$loading of 2 to $9 \mathrm{May}$ 1989, $P_{\mathrm{m}}{ }^{\mathrm{B}}$ and $\alpha^{\mathrm{B}}$ initially dropped to $<2$ and $<0.02$, respectively, then rebounded to levels higher than initial values for the duration of the bloom. As the bloom declined between 23 May and 8 June, $P_{\mathrm{m}}{ }^{\mathrm{B}}$ and $\alpha^{\mathrm{B}}$ dropped to less than half their pre-bloom and midbloom values (Fig. 2C). Measured values of $\alpha^{B}$ were more variable than measured $k_{\mathrm{C}}$ (Fig. 2D), and variations in the two were uncorrelated. Hence the variability in $\alpha^{B}$ was dominated by changes in calculated values of $\phi$.

At $\operatorname{Stn} 4 \mathrm{~B}$ in the lower sub-estuary, chlorophyll concentration was about $80 \mu \mathrm{g}^{-1}$ prior to the arrival of the freshwater pulse from the Susquehanna, which was indicated by the drop in salinity at $\operatorname{Stn} 4 \mathrm{~B}$ between 11 

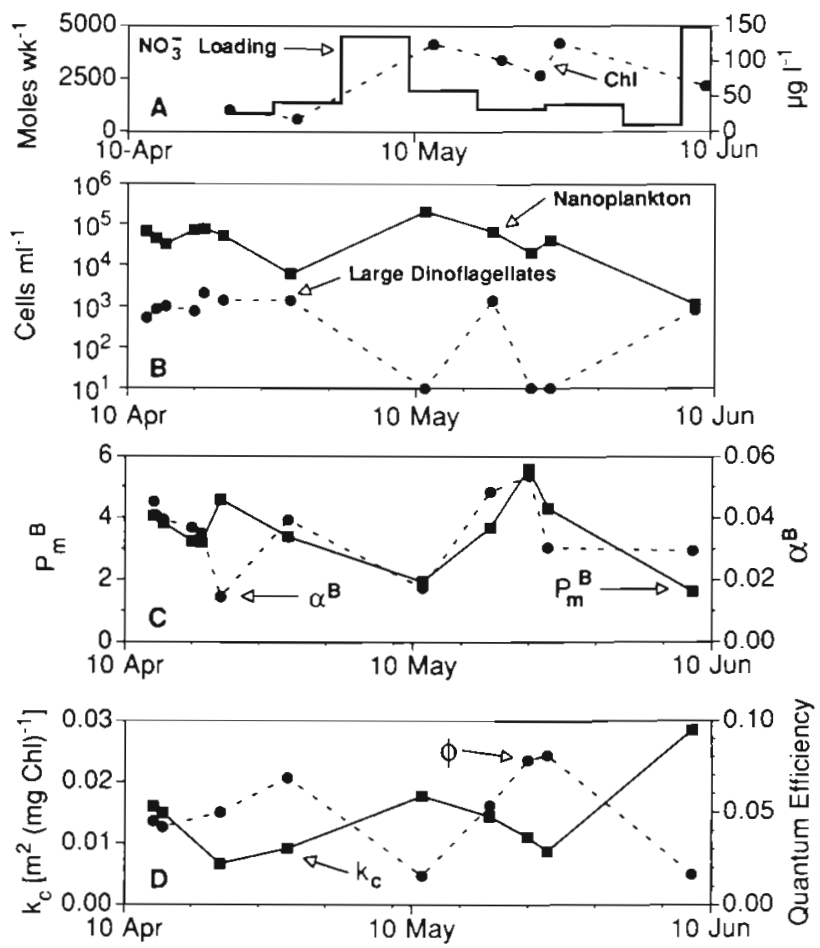

Fig. 2. Response of biomass, populations, and photosynthetic parameters to watershed inputs from 12 April to 8 June 1989 , at the upper sub-estuary station (Stn 5B). (A) Chlorophyll biomass in relation to $\mathrm{NO}_{3}{ }^{-}$loading from the local watershed; (B) cell concenstrations of nanoplankton and large dinoflagellates; (C) photosynthetic maximum, $P_{\mathrm{m}}{ }^{\mathrm{B}}\left[\mathrm{mg} C(\mathrm{mg} \mathrm{chl})^{-1} \mathrm{~h}^{-1}\right.$ ] and initial slope, $\alpha^{B}\left[\mathrm{mg} \mathrm{C}(\mathrm{mg} \mathrm{chl})^{-1} \mathrm{~h}^{-1}\left[\mu \mathrm{mol} \mathrm{m} \mathrm{m}^{-2} \mathrm{~s}^{-1}\right]^{-1}\right.$; (D) chlorophyll-specific absorption, $k_{\mathrm{C}}$, and quantum efficiency, $\phi$, $\left[(\mathrm{mol} \mathrm{C} \text { fixed)(mol quanta absorbed })^{-1}\right]$

and 18 May 1989, i.e. about 9 d after the local rainfall (Fig. 3A). After salinity stabilized at about $4.5 \mathrm{ppt}$, chlorophyli increased from 80 to $160 \mathrm{\mu g} \mathrm{l}^{-1}$. As at the upper sub-estuary station, the bloom consisted primarily of small phytoplankton, principally cryptomonads, Microcystis sp., and Thalassiosira pseudonana (Table 1), and chlorophyll changes more closely tracked numbers of nanoplankton (Fig. 3B).

Photosynthetic parameters at the lower sub-estuary (Stn 4B; Fig. 3C) followed a very similar pattern to that at $\mathrm{Stn} 5 \mathrm{~B}$; i.e. typical values were observed prior to the arrival of the freshwater pulse, followed by high values near the end of May, then by lower values in early June as numbers of nanoplankton decreased sharply (Fig. 3C). During the period of dominance by nanoplankton (10 April to $24 \mathrm{May}$ ) both $k_{\mathrm{c}}$ [ca 0.007 to 0.014 $\mathrm{m}^{2}$ (mg chl $)^{-1}$ ] and $\phi[\mathrm{ca} 0.015$ to $0.03 \mathrm{~mol} \mathrm{C}$ (mol quanta $^{-1}$ ] varied by about a factor of 2 (Fig. 3D).

Theory predicts that the maximum aerial standing crop and potential depth-integrated productivity will increase as depth decreases in a system (Takahashi \& Parsons 1972). Due to compression of the photic zone
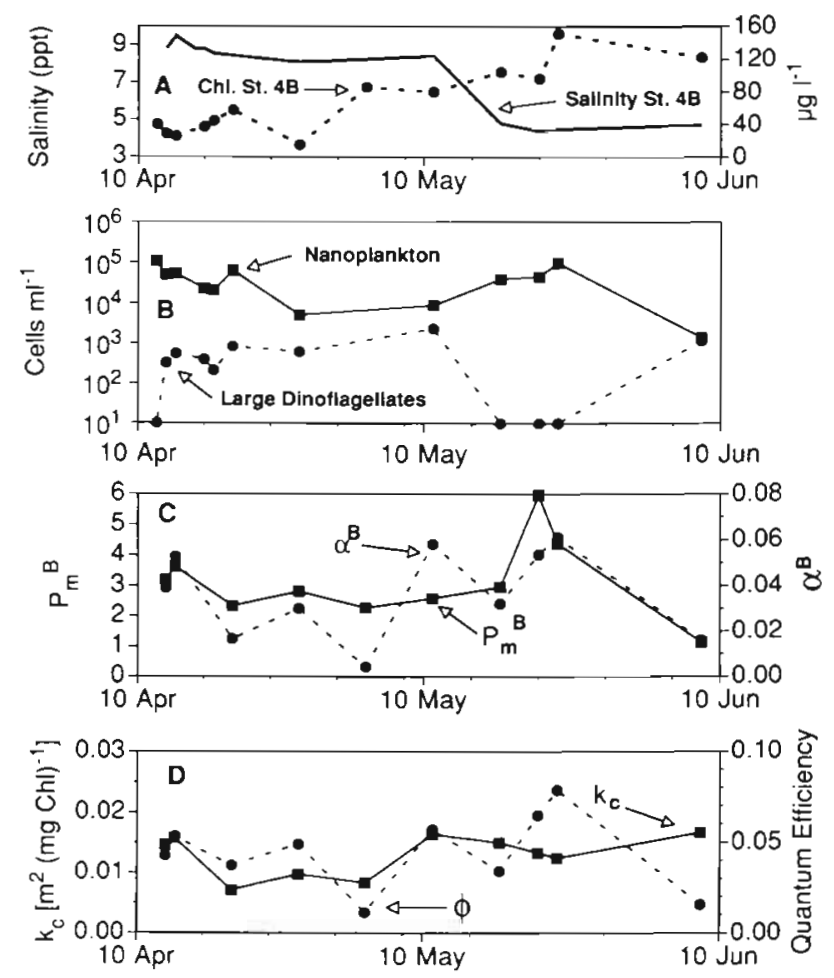

Fig. 3. (A) Response of chlorophyll at lower sub-estuary station (Stn $4 \mathrm{~B}$ ) to salinity drop due to arrival of freshwater pulse from Susquehanna River from storm 2 wk earlier. (B), (C), (D) as Fig. 2

by increases in chlorophyll however, the increment in depth-integrated productivity should generally be less than the increases in volumetric chlorophyll concentration, unless, as was the case here, there are simultaneous changes in photosynthetic parameters (Fig. 4). Thus, the initial increase in chlorophyll at the upper sub-estuary station on 11 May had no impact on $\int P_{d}$ (Fig. 4A) due to the initial declines in photosynthetic parameters. The following week $\int P_{\mathrm{d}}$ was maximal and the increment was roughly proportional to the incremental increase in chlorophyll, due to the coincident increases in $\alpha^{B}$ and $P_{\mathrm{m}}{ }^{\mathrm{B}}$. The decrease in productivity on the next 2 sampling dates, in spite of continued high photosynthetic parameters and increasing chlorophyll, was due to increases in diffuse attenuation coefficient from $<1 \mathrm{~m}^{-1}$ on 11 May to $3.75 \mathrm{~m}^{-1}$ on 24 May. Very similar patterns were observed at the lower subestuary station (Fig. 4B). At both stations, the effect of day-to-day variations in cloud cover was assessed by calculating $\int P_{\mathrm{d}}$ for all days using incident irradiance measured on a cloudless day (Fig. 4, dashed line). While cloud cover reduced calculated productivity by 30 to $40 \%$ on several days, the day-to-day changes were much greater than this, and hence the temporal pattern was more strongly governed by other factors. 
Table 1. Variation of phytoplankton abundance with time at Stn 4B, 27 April to 24 May 1989, and with location on 14 July 1989. Units of abundance are cells $\mathrm{ml}^{-1} \mathrm{P}=$ present at $<10^{2} \mathrm{ml}^{-1}$

\begin{tabular}{|c|c|c|c|c|c|c|c|c|c|c|}
\hline & \multicolumn{5}{|c|}{ Stn 4B, 27 April-24 May 1989} & \multicolumn{5}{|c|}{ Location on 14 July 1989} \\
\hline & $27 \mathrm{Apr}$ & 11 May & 18 May & 22 May & 24 May & $\operatorname{Stn} 1 B$ & $\operatorname{Stn} 2 B$ & Stn $3 B$ & $\operatorname{Stn} 4 \mathrm{~B}$ & Stn $5 B$ \\
\hline \multicolumn{11}{|l|}{ Nanoplankton } \\
\hline Cryptomonas sp. & 360 & 3600 & 4300 & 1500 & 1200 & 1800 & 1700 & 800 & 1300 & $\mathrm{P}$ \\
\hline Thalassiosira pseudonana & 3000 & 1200 & 34000 & 40000 & 60000 & 850 & 3300 & 4000 & 520 & 4700 \\
\hline Microcystis sp. & & & $P$ & 1600 & 36000 & 8000 & 4500 & 11000 & 520 & $\mathrm{P}$ \\
\hline Microcystis aeruginosa & 1500 & 1400 & & & 4100 & 250 & & & & \\
\hline Cyclotella glomerata & 770 & $\mathrm{P}$ & $\mathrm{P}$ & 900 & $\mathrm{P}$ & 920 & 1800 & 360 & P & $\mathrm{P}$ \\
\hline Pyramimonas sp. & $\mathrm{P}$ & & 650 & $\mathrm{P}$ & $P$ & 500 & 340 & $\mathrm{P}$ & 490 & $\mathrm{P}$ \\
\hline Gyrodinium estuariale & 1100 & 4200 & 470 & $P$ & $\mathrm{P}$ & $\mathrm{P}$ & $\mathrm{P}$ & & & \\
\hline Katodinium rotundatum & & 1900 & 1600 & & $\mathrm{P}$ & & $\mathrm{P}$ & $\mathrm{P}$ & $\mathrm{P}$ & \\
\hline Unidentified haptophyte & & $\mathrm{P}$ & 770 & 650 & $\mathrm{P}$ & & & & & \\
\hline Aphanizomenon sp. 1 & & & & $\mathrm{P}$ & 1500 & & 130 & & & \\
\hline Chrysochromulina sp. & 310 & & $\mathrm{P}$ & & $\mathrm{P}$ & & P & & & \\
\hline Trachelomonas sp. & & & & & $P$ & $\mathrm{P}$ & 130 & 570 & 520 & \\
\hline Eutreptia sp. & & $\mathrm{P}$ & $\mathrm{P}$ & & & $P$ & P & 410 & 520 & \\
\hline Chaetoceros affinis & & & & & 220 & $P$ & $P$ & & $\mathrm{P}$ & \\
\hline \multicolumn{11}{|l|}{ Large dinoflagellates } \\
\hline Gymnodinium sp. \#2 & $\mathrm{P}$ & 360 & $\mathrm{P}$ & $\mathrm{P}$ & $\mathrm{P}$ & $\mathrm{P}$ & 360 & $\mathrm{P}$ & $\mathrm{P}$ & 5000 \\
\hline Gymnodinium sp. \#3 & & 1700 & $\mathrm{P}$ & & $\mathrm{P}$ & & 700 & 130 & 2700 & 7700 \\
\hline Gyrodinium uncatenum & & 310 & $\mathrm{P}$ & & $\mathrm{P}$ & $\mathrm{P}$ & 1100 & 460 & 1700 & 4600 \\
\hline Scrippsiella trochoidea & & & $\mathrm{P}$ & & & $\mathrm{P}$ & 1300 & 670 & 1200 & 2200 \\
\hline
\end{tabular}

\section{June to 20 July 1989}

Two events resulted in high nitrate loading to the upper sub-estuary during the second observation period. The first was due to a sustained rainy period during the first $3 \mathrm{wk}$ in June (Fig. 5A, cf. Fig. 2A). Chlorophyll at $\operatorname{Stn} 5 B$ in the upper sub-estuary bloomed from ca $60 \mu \mathrm{gl}^{-1}$ to $>500 \mu \mathrm{g} \mathrm{l}^{-1}$ on 19 June

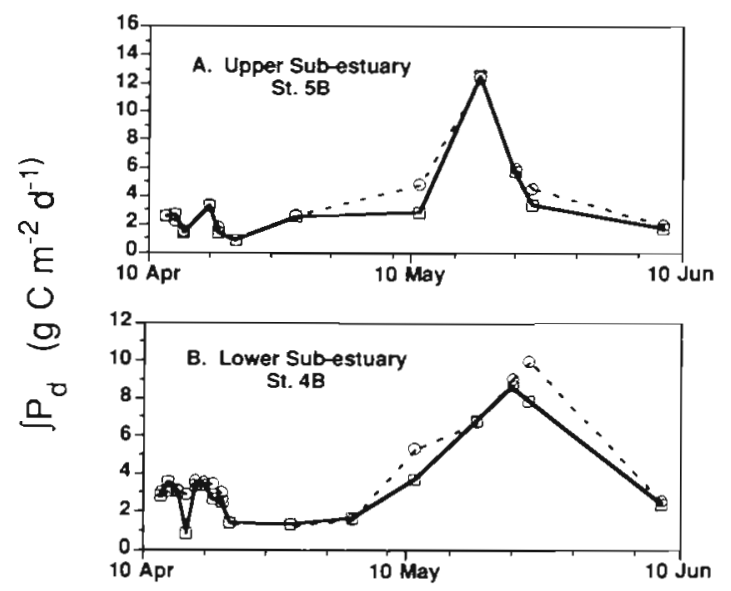

Fig. 4. Rates of gross daily production from 12 April to 8 June 1989, as calculated from biomass and photosynthesisirradiance curves for (A) upper sub-estuary station (Stn 5B), and $(B)$ lower sub-estuary station (Stn $4 B)(=-Z)$ Calculated using incident irradiance measured on sampling day; $c$ - - ) calculated using incident irradiance measured on a clear-sky day
1989; changes in chlorophyll most closely paralleled changes in the large dinoflagellate cell numbers (Fig. 5B). The second influx of $\mathrm{NO}_{3}{ }^{-}$from the Muddy Creek watershed was the result of a $2 \mathrm{~d}$ storm in early July.
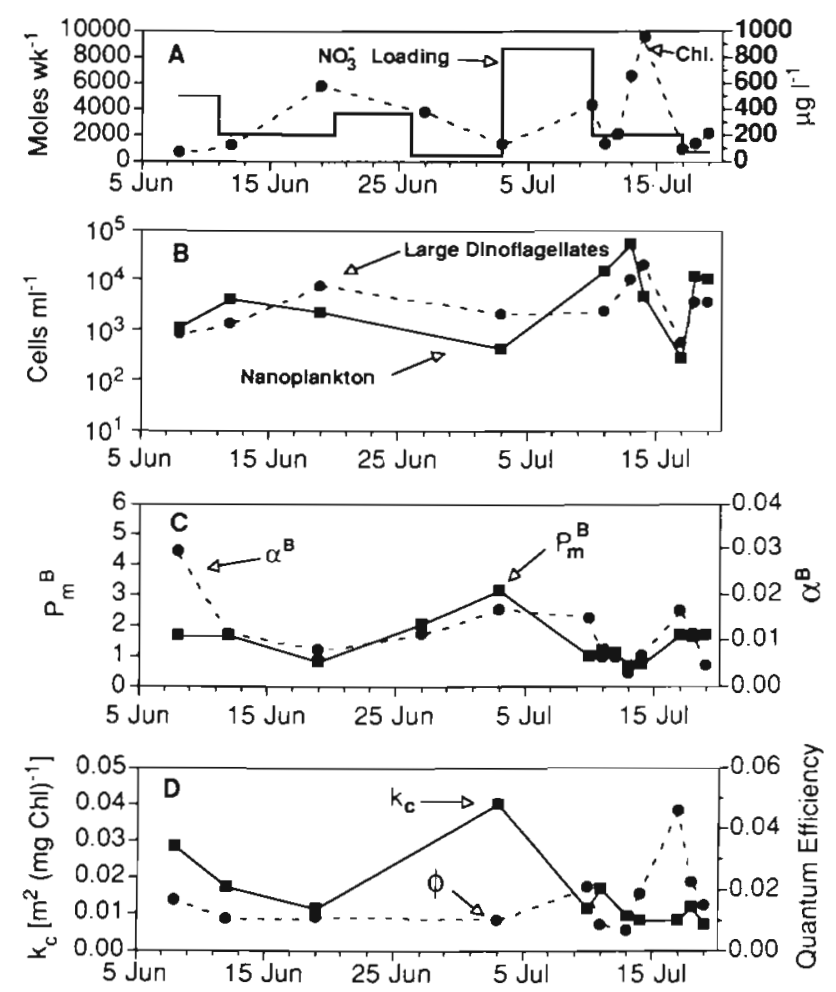

Fig. 5. As Fig. 2 but for 8 June to 19 July 1989 
After an initial decline, chlorophyll rose over the next 3 $\mathrm{d}$, peaked at nearly $1000 \mu \mathrm{g} \mathrm{l}^{-1}$, then declined again. Blooms throughout the sub-estuary during June-July consisted primarily of the large dinoflagellates Gymnodinium sp. 2 and 3, Gyrodinium uncatenum, and Scripsiella trochoidea. The principal differences in species composition at the peak of the bloom occurred spatially, with large dinoflagellates being $<10^{2} \mathrm{ml}^{-1}$ at Stn $1 B$, and increasing in numbers upstream (Table 1), Although densities of nanoplankton and large dinoflagellates covaried, peak chlorophyll coincided with peak numbers of large dinoflagellates

Photosynthetic parameters, which had declined at the close of the first bloom period in May (cf. Fig. 2C) declined even further, with $P_{\mathrm{m}}{ }^{\mathrm{B}}$ and $\alpha^{\mathrm{B}}$ reaching local minima $\left(P_{\mathrm{m}}{ }^{\mathrm{B}}=0.8, \alpha^{\mathrm{B}}=0.008\right)$ on 19 June, the day of the first peak in chlorophyll concentration (Fig. 5C). Photosynthetic parameters varied roughly inversely with chlorophyll, until the bloom that peaked on 14 July, when parameters were so low that changes were undiscernable. In contrast with photosynthetic parameters, $k_{\mathrm{c}}$ was as high and as variable during June-July as during the $10 \mathrm{April}$ to 10 June period. Photosynthetic parameters at Stn $5 \mathrm{~B}$, especially $P_{\mathrm{m}}{ }^{\mathrm{B}}$ but also $\alpha^{\mathrm{B}}$, were positively correlated with $k_{c}$ (Fig. 5D). Therefore inferred values of $\phi$ were low and relatively uniform; $\phi$ exceeded 0.04 on one occasion, and was otherwise $<0.03$ with a minimum $<0.005$.

At the lower sub-estuary station (4B; Fig. 6), salinity was much lower than the seasonal average (Jordan et al. 1991) and chlorophyll was at bloom levels throughout most of the June-July period (Fig. 6A). Visually it is difficult to relate chlorophyll changes to either of the gross taxonomic groupings, but nanoplankton were generally an order of magnitude less abundant and large dinoflagellates an order of magnitude more abundant compared with the April-May period at the same station (cf. Figs. $6 \mathrm{~B} \& 3 \mathrm{~B}$ and Table 1).

Photosynthetic parameters at Stn $4 B$ during the second bloom period exhibited similar patterns as at Stn 5B; i.e. $P_{m}{ }^{\mathrm{B}}$ and $\alpha^{\mathrm{B}}$ were low and varied inversely with chlorophyll (cf. Figs. 6C \& 5C). Chlorophyll-specific absorption was less variable at the lower sub-estuary station, but calculated quantum efficiencies were similarly low and uniform, averaging 0.01 (Fig. 6D).

Variations in $\int P_{\mathrm{d}}$ tracked changes in chlorophyll, but were also influenced by changes in photosynthetic parameters (Fig. 7). For example, in June chlorophyll peaked on June 19, but $\int P_{\mathrm{d}}$ peaked the following week, due to increases in both $P_{\mathrm{m}}{ }^{\mathrm{B}}$ and $\alpha^{\mathrm{B}}$. Similarly, changes in $\int P_{\mathrm{d}}$ during the July bloom are clearly related to chlorophyll changes. Note, however, that the $y$-axis scale in Fig. 7 is half that in Fig. 4. Thus, due to the much reduced photosynthetic parameters during the June-July period, $\int P_{\mathrm{d}}$ was lower than during the
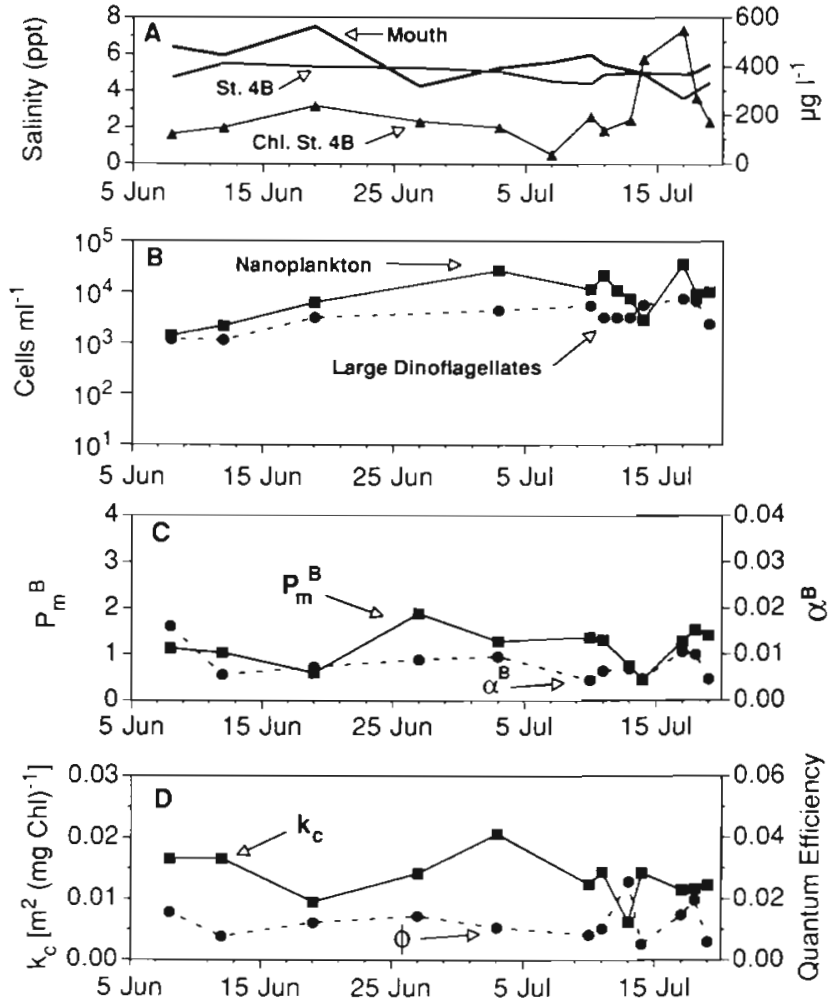

Fig. 6. As Fig. 3, but for 8 June to 19 July 1989. Salinity at mouth of Rhode River is shown in (A) to indicate arrival of attenuated pulse from Susquehanna River on 27 June

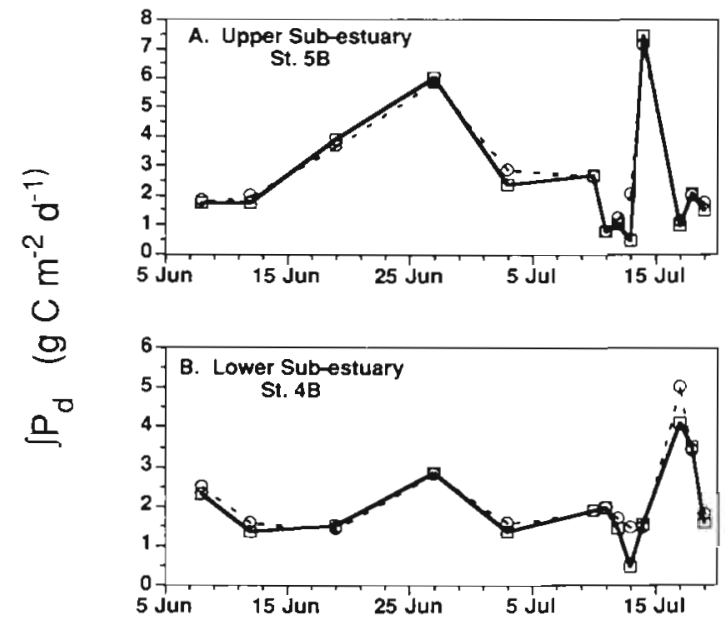

Fig. 7. As Fig. 4 but for 8 June to 19 July 1989. Note $y$-axis scale is half that in Fig. 4

May bloom, even though chlorophyll levels were much higher.

\section{Photosynthetic parameters and species composition}

Values of cellular carbon and predicted growth rates and assimilation number for the species observed to be 
dominant over 5 sampling periods at Stn $4 \mathrm{~B}$ during the first bloom, and over 5 stations at the peak of the second bloom, are given in Table 2 . When the speciesspecific $P_{\mathrm{m}}{ }^{\mathrm{B}}$ and carbon contents are combined with the abundance data in Table 1 , the predicted $P_{\mathrm{m}}{ }^{\mathrm{B}}$ for the mixed assemblages ranged from $<1$ to 7.1 and slightly overestimated but correlated well with observed data (Fig. 8A; $\mathrm{r}^{2}=0.77$, slope of predicted versus observed $=1.27, \mathrm{SE}=0.25$ ).

While there is no basis in the equations of Banse (1982) for predicting the value of $\alpha^{B}$ from species composition, Cullen (1990), analysing the model of Sakshaug et al. (1989), showed that

$$
P_{\mathrm{m}}^{\mathrm{B}}=\frac{k_{\mathrm{c}} \cdot \phi}{\sigma \tau}
$$

where $\sigma=$ absorption cross section of the photosynthetic unit; and $\tau=$ turnover time of the photosynthetic unit. No size- and taxa-dependent compilation of these parameters has been made, but Eq. (6) provides a physiological basis for the correlation between $\alpha^{B}$ and $P_{\mathrm{m}}{ }^{\mathrm{B}}$ frequently observed (e.g. Harding et al. 1985). Such a correlation was observed here (Fig. 8B), and the same relationship between $P_{\mathrm{m}}^{\mathrm{B}}$ and $\alpha^{\mathrm{B}}$ was maintained across large changes in species composition and chlorophyll concentrations (cf. Table 1, Figs. 2, 3, 5 \& 6) These results suggest taxon-dependence of $\alpha^{B}$ due to its close coupling with $P_{\mathrm{m}}{ }^{\mathrm{B}}$ (Eq. 6) which, in turn, is coupled with growth rate (Eq. 5)

\section{DISCUSSION}

The results demonstrate the potential impact of species composition on $\int P_{\mathrm{d}}$. Photosynthetic parameters increased during the first bloom as Thalassiosira pseudonana proliferated (Figs. $2 \& 3$, Table 1) with the result that calculated gross daily productivity increased by a factor greater than the increment in chlorophyll (Fig. 4). Conversely, during the dinoflagellate-dominated bloom of June-July the overall levels of $\int P_{\mathrm{d}}$ were lower than the previous period, despite higher chlorophyll concentrations, due to the lower values of $P_{\mathrm{m}}{ }^{\mathrm{B}}$ and $\alpha^{\mathrm{B}}$ for that assemblage. Nevertheless, predictions of $P_{\mathrm{m}}{ }^{\mathrm{B}}$ during both periods assumed the species present were growing at maximal rates (see below).

Surprisingly little of the difference in $\alpha^{B}$ between the 2 periods was attributable to $k_{c}$ (cf. Figs. 2D, 3D, 5D \& 6D). This observation has implications for bio-optical approaches to estimating primary production whereby variability in $\alpha^{\mathrm{B}}$ is attributed to changes in $k_{\mathrm{C}}$, with $\phi$ held constant. The degree to which $\alpha^{\mathrm{B}}$ is controlled by $k_{\mathrm{c}}$ rather than $\phi$ deserves further study.

The dependence of $P_{\mathrm{m}}{ }^{\mathrm{B}}$ on species composition of the

Table 2. Cellular carbon contents and predicted growth and light-saturated photosynthetic rates for dominant species during late spring and early summer 1989 in the Rhode River, Maryland. $P_{\mathrm{m}}{ }^{\mathrm{B}}$ calculations based on C:chl, $\theta=40 \mathrm{mg} \mathrm{C} \mathrm{(mg} \mathrm{chl} \mathrm{a)}{ }^{-1}$, and daylength, $D=14 \mathrm{~h}$

\begin{tabular}{|c|c|c|c|}
\hline Species & $\begin{array}{c}\text { Carbon } \\
\left(\mathrm{pg} \text { cell }{ }^{-1}\right)\end{array}$ & $\begin{array}{c}\text { Growth } \\
\left(d^{-1}\right)\end{array}$ & 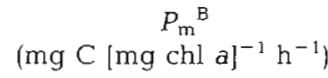 \\
\hline \multicolumn{4}{|l|}{ Nanoplankton } \\
\hline Thalassiosira pseudonana & 7.92 & 2.31 & 7.58 \\
\hline Cyclotella glomerata & 20.46 & 2.04 & 6.70 \\
\hline Chaetoceros affinis & 155.18 & 1.57 & 5.15 \\
\hline Cryptomonas sp. & 55.38 & 1.43 & 4.68 \\
\hline Microcystis aeruginosa & 7.26 & 1.89 & 6.22 \\
\hline Unidentified haptophyte & 3.44 & 2.10 & 6.91 \\
\hline Pyramimonas sp. & 39.76 & 1.49 & 4.91 \\
\hline Microcystis sp. & 1.20 & 2.44 & 8.00 \\
\hline Aphanizomenon sp. 1 & 33.56 & 1.53 & 5.02 \\
\hline Chrysochromulina sp. & 100.51 & 1.31 & 4.31 \\
\hline Synura sp. & 4.30 & 2.04 & 6.69 \\
\hline Trachelomonas sp. & 334.09 & 1.11 & 3.64 \\
\hline Eutreptia sp. & 61.02 & 1.41 & 4.62 \\
\hline Gyrodinium estuariale & 131.47 & 0.66 & 2.18 \\
\hline Prorocentrum minimum & 153.96 & 0.65 & 2.13 \\
\hline Katodinium rotundatum & 21.12 & 0.87 & 2.87 \\
\hline \multicolumn{4}{|l|}{ Large dinoflagellates } \\
\hline Gymnodinium sp. \#2 & 1981.39 & 0.44 & 1.45 \\
\hline Gymnodinium sp. \#3 & 4290.03 & 0.39 & 1.29 \\
\hline Gyrodinium uncatenum & 2806.23 & 0.42 & 1.38 \\
\hline Scrippsiella trochoidea & 1577.10 & 0.46 & 1.50 \\
\hline
\end{tabular}



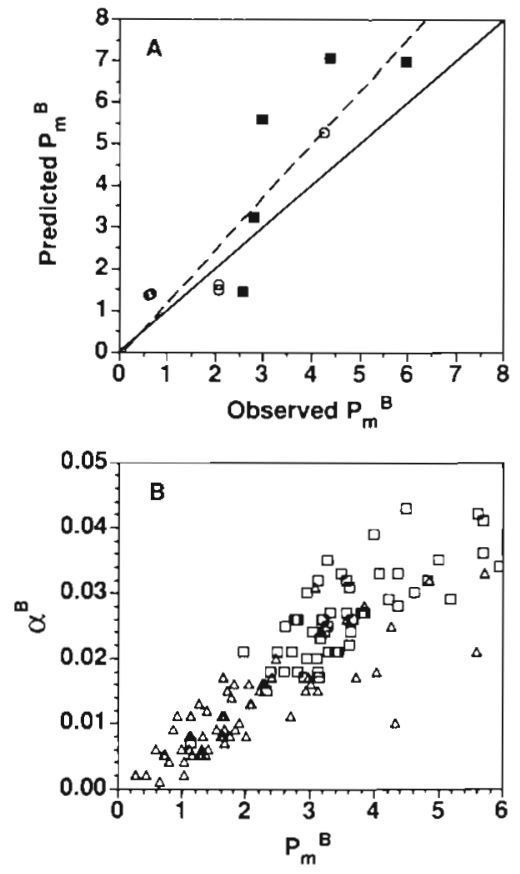

Fig. 8. (A) Light-saturated photosynthetic rates, $P_{r n}{ }^{B}$, predicted from species composition data and size and taxon-dependent growth rates versus measured $P_{\mathrm{m}}^{\mathrm{B}}$ (ロ) 27 April to 24 May 1989 at $\operatorname{Stn} 4 \mathrm{~B}_{;}(\odot)$ Stn $1 \mathrm{~B}$ to $5 \mathrm{~B}$ on 14 July $1989 .(--)$ Least squares regression; (-) 1.1 correspondence. (B) Relationship of $\alpha^{B}$ to $P_{\mathrm{m}}{ }^{\mathrm{B}}$ for the 2 bloom periods, and all stations. (c) 12 April to 8 June 1989; ( 14 June to 24 July 1989 . Units of $P_{\mathrm{m}}^{\mathrm{B}}$ are [mg C

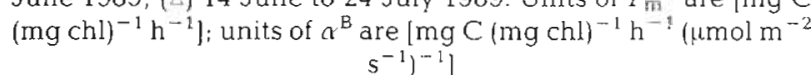

phytoplankton assemblage has been noted in other studies (Côté \& Platt 1983, Harris et al. 1983, Sephton \& Harris 1984). Joint \& Pomroy (1988) predicted productivity maxima from species composition and taxon- and size-specific growth rates, but they did not attempt to predict pigment-normalized, light-saturated photosynthesis. The success of that prediction in this analysis may seem surprising in view of the large number of factors known to influence photosynthetic parameters (Falkowski 1981). Consideration of some commonly cited factors will help to circumscribe the results and to evaluate the factors controlling primary productivity in nutrient-rich estuaries.

The light-saturated photosynthetic rate, being an enzymatic process, is temperature-dependent with $Q_{10}$ values clustering around 2 (Harris 1978). Between the 4 May and 11 May sampling dates, temperature at Stn $4 \mathrm{~B}$ decreased from 18 to $13^{\circ} \mathrm{C}$. Otherwise temperature during the first period for which predictions were attempted varied only between 18 and $21^{\circ} \mathrm{C}$, which is insufficient to account for the variation observed. Temperature varied $<1{ }^{\circ} \mathrm{C}$ among the 5 stations on 14 July. A plot of $P_{\mathrm{m}}{ }^{\mathrm{B}}$ versus temperature over several seasons at this site (Gallegos unpubl.) is bounded above by Eppley's (1972) equation but many points fall well below the upper bound, as has been observed in other coastal regions (Pennock \& Sharp 1986, Keller 1989). Côté \& Platt (1983), who observed positive correlation of $P_{\mathrm{m}}{ }^{\mathrm{B}}$ with temperature, attributed the result to changes in species assemblages, with species having higher P-I parameters predominating during warmer periods, rather than temperature effect on photosynthesis per se. Here, the warmer temperatures favored development of assemblages with lower photosynthetic capacity

Light-shade adaptation is known to influence $P_{\mathrm{m}}{ }^{\mathrm{B}}$ (Falkowski 1981); vertical variations in photosynthetic parameters develop under stratified conditions (e.g. Gallegos et al. 1983) and temporal adaptations as cells undergo displacement through the vertical light gradient can influence production in well-mixed layers (Lewis et al. 1984). The equation relating photosynthesis to growth rate purportedly applies to adapted rates of photosynthesis (Sakshaug et al. 1989), and is not expected to describe plots of instantaneous P-I curves as were measured here (Cullen 1990).

While laboratory studies have probed deeply into the physiological bases of light-shade adaptation (Perry et al. 1981, Prézelin 1981), at the resolution of this study the photoadaptive property of major concern is the carbon:chlorophyll ratio, $\theta$ (Falkowski 1981, Geider et al. 1986). The use of a constant $\theta$ is the most tenuous of the assumptions used to predict $P_{\mathrm{m}}{ }^{\text {B }}$ from species composition, due to the known tendency for $\theta$ to be higher in dinoflagellates than in diatoms (e.g. Chan 1980, Geider et al. 1986). It is possible, however, that adaptation of $\theta$ to the reduced light availability may have offset the tendency for $\theta$ to increase due to taxonomic differences. Diffuse attenuation coefficients during April-May generally ranged from 1 to $2 \mathrm{~m}^{-1}$, compared with 3 to $5 \mathrm{~m}^{-1}$ during the period of dinoflagellate dominance. Thus the cells experienced much lower light intensities during June-July, which would create conditions for increased cellular chlorophyll concentrations and consequent reduced carbon:chlorophyll ratios.

Another assumption of the analysis is that the species present are growing at the nutrient-saturated rates for their size and coarse taxonomic groupings. The assumption is based on the low $\mathrm{N}$ : P ratios that prevail during the late spring and summer and the continual presence of dissolved $\mathrm{NH}_{4}{ }^{+}$at 4 to $5 \mu \mathrm{M}$ (Jordan et al. 1991). Based strictly on the continual presence of dissolved macronutrients, the assumption of nutrient sufficiency seems reasonable. Nevertheless, closer examination of the data may reveal some evidence of nutrient limitation. The lowest $P_{\mathrm{m}}{ }^{\mathrm{B}}$ predicted for any of the large dinoflagellates (Table 2) was $1.3 \mathrm{mg} \mathrm{C}(\mathrm{mg} \mathrm{chl})^{-1} \mathrm{~h}^{-1}$, close to values observed on 10 to 12 July (Figs. $7 \mathrm{C} \&$ 
9C). As the bloom peaked on 14 July, however, observed values were only $0.62 \mathrm{mg} C(\mathrm{mg} \mathrm{chl})^{-1} \mathrm{~h}^{-1}$. Although the observed value is about half that predicted, the difference is small compared with the range of observed values $(0.62$ to 6.0$)$. Thus it appears that the prediction of $P_{\mathrm{m}}{ }^{\mathrm{B}}$ from species composition worked here because the predicted growth rates for large dinoflagellates found here conform to the size dependent relationships of Banse (1982) and were so much lower than those of small diatoms (Table 2); further reductions due to nutrient limitation, if it indeed occurred, were of second-order importance here.

Changes in species abundance is the time-integral (after correcting for horizontal mixing and exchange) of the net growth rate, i.e. the difference between gross growth rate and the sum of all loss rates. The foregoing analysis assumed that differences $P_{\mathrm{m}}{ }^{\mathrm{B}}$ were attributable to species-specific differences in maximal growth rates. The observation that slower growing species (large dinoflagellates) sometimes bloomed while faster growing species (nanoplankton) declined implies that species-specific differences in loss rates also occurred, with slower-growing species necessarily having lower loss rates during such periods. Although loss rates were not observed in this study, Reynolds et al. (1982) demonstrated that selective loss processes were a major determinant of species abundance patterns in large limnetic enclosures. Given the quantitative connection demonstrated here between $P_{\mathrm{m}}{ }^{\mathrm{B}}$ and the species present, it is worth re-emphasizing the importance of loss processes in determining both the production rate of the phytoplankton community and its eventual fate (e.g. Harris 1986).

When watershed inputs favored development of dinoflagellate blooms, photosynthetic parameters were reduced, and the relative fluctuations in rates of production were lower than those of pigment biomass. Thus carbon input to the plankton foodweb would appear to be at least partially buffered against large interannual variations in hydrologic forcing at local and regional scales. Due to large changes in phytoplankton community structure, however, qualitative effects on foodweb structure may be pronounced.

In environments meeting the criteria of nutrientsufficiency and having species assemblages conforming to the size-growth relationships of Banse (1982), these results suggest that data on species composition may be of value in making quantitative predictions of P-I parameters; their utility in remote sensing models follows directly. While the seasonal periodicity of some species and the temporal persistence of others (e.g. Riley 1967, Day et al. 1989) may facilitate such predictions, interannual variability in species composition, particularly in relation to the occurrence of sporadic blooms, can be expected to be large (Mallin et al. 1991).
Understanding the life history patterns determining growth and loss rates of dominant phytoplankters in relation to environmental variability at local and regional scales may, therefore, be of equal importance in predicting production dynamics in such environments as is a deeper understanding of the mechanistic bases of photosynthesis.

Acknowledgements. I thank S. Hedrick for assistance with field work and analysis of phytoplankton samples. Portions of the data on phytoplankton carbon content were made available by K. Sellner. Comments by R. Geider, $T$ Malone, and T. Jordan improved the manuscript. This study was funded by the Smithsonian Environmental Sciences Program.

\section{LITERATURE CITED}

Banse, K. (1982). Cell volumes, maximal growth rates of unicellular algae and ciliates, and the role of ciliates in the marine pelagial. Limnol. Oceanogr. 27 1059-1071

Boulding, E. G., Platt, T. (1986). Variation in photosynthetic rates among individual cells of a marine dinoflagellate. Mar. Ecol. Prog. Ser. 29: 199-203

Bricaud, A., Stramski, D. (1990). Spectral absorption coefficients of living phytoplankton and nonalgal biogenous matter a comparison between the Peru upwelling area and the Sargasso Sea. Limnol. Oceanogr. 35: 562-582

Chan, A. T (1980). Comparative physiological study of marine diatoms and dinoflagellates in relation to irradiance and cell size. II. Relationship between photosynthesis, growth, and carbon/chlorophyll a ratio. J. Phycol. 16: 428-432

Côté, B., Platt, T (1983). Day-to-day variations in the springsummer photosynthetic parameters of coastal marine phytoplankton. Limnol. Oceanogr. 28: 320-344

Cullen, J. J. (1990). On models of growth and photosynthesis in phytoplankton. Deep Sea Res. 37: 667-683

Day, J. W., Hall, C. A. S., Kemp, W. M., Yanez-Arancibia, A (1989). Estuarine phytoplankton. In: Estuarine ecology John Wiley and Sons, New York, p. 147-187

Eppley, R. W. (1972). Temperature and phytoplankton growth in the sea. Fish. Bull. U.S. 70: 1063-1085

Falkowski, P. G. (1981). Light-shade adaptation and assimilation numbers. J. Plankton Res. 3: 203-216

Gallegos, C. L., Correll, D. L., Pierce, J. W. (1990). Modeling spectral diffuse attenuation, absorption, and scattering coefficients in a turbid estuary. Limnol. Oceanogr. 35: 1486-1502

Gallegos, C. L., Jordan, T E., Correll, D. L. (1992). Event-scale response of phytoplankton to watershed inputs in a subestuary: timing, magnitude and location of blooms. Limnol. Oceanogr (in press)

Gallegos, C. L., Platt, T., Harrison, W. G., Irwin, B. (1983). Photosynthetic parameters of arctic marine phytoplankton: vertical variations and time scales of adaptation. Limnol. Oceanogr. 28: 698-708

Geider, R. J., Platt, T., Raven, J. A. (1986). Size dependence of growth and photosynthesis in diatoms: a synthesis. Mar Ecol. Prog. Ser. 30: 93-104

Harding, L. W., Jr, Meeson, B. W., Fisher, T R., Jr (1985). Photosynthesis patterns in Chesapeake Bay phytoplankton: short-and long-term responses of P-I curve parameters to light. Mar Ecol. Prog. Ser. 26: 99-111

Harris, G. P. (1978). Photosynthesis, productivity and growth: the physiological ecology of phytoplankton. Arch. Hy drobiol. Beih. Ergebn. Limnol. 10: 1-171 
Harris, G. P. (1986). Phytoplankton ecology: structure, function and fluctuation. Chapman and Hall, New York

Harris, G. P., Piccinin, B. B., van Ryn, J. (1983). Physical variability and phytoplankton communities: $V$. cell size, niche diversification and the role of competition. Arch. Hydrobiol. 98: 215-239

Harrison, W G., Platt, T (1980). Variations in assimilation number of coastal marine phytoplankton: effects of environmental co-variates. J. Plankton Res. 2: 249-260

Harrison, W. G., Platt, T (1986). Photosynthesis-irradiance relationships in polar and temperate phytoplankton populations. Polar Biol. 5: 153-164

Jassby, A. D., Platt, T. (1976). Mathematical formulation of the relationship between photosynthesis and light for phytoplankton. Limnol Oceanogr 21: 540-547

Jeffrey, S. W., Humphrey, G. F. (1975). New spectrophotometric equation for determining chlorophyll $a, b, c^{1}$, and $c^{2}$ in higher plants, algae, and natural phytoplankton. Biochem. Physiol. Pflanz. 167: 191-194

Joint, I. R., Pomroy, A. J. (1988). Allometric estimation of the productivity of phytoplankton assemblages. Mar. Ecol. Prog. Ser. 47: 161-168

Jordan, T E., Correll, D. L., Miklas, J., Weller, D. E. (1991). Nutrients and chlorophyll at the interface of a watershed and an estuary. Limnol. Oceanogr. 36: 251-267

Keller, A. A. (1989). Modeling the effects of temperature, light, and nutrients on primary productivity: an empirical and mechanistic approach compared. Limnol. Oceanogr 34: $82-96$

Kiefer, D. W., SooHoo, J. B. (1982). Spectral absorption by marine particles of coastal waters of Baja California. Limnol. Oceanogr. 27: 492-499

Kishino, M., Takahashi, M., Okami, N., Ichimura, S. (1985). Estimation of the spectral absorption coefficients of phytoplankton in the sea. Bull. mar. Sci. 37: 634-642

Lewis, M. R., Horne, E. P. W. Cullen, J. J., Oakey, N. S., Platt, $T$ (1984). Turbulent motions may control phytoplankton photosynthesis in the upper ocean. Nature, Lond. 311. $49-50$

Lewis, M. R., Smith, J. C. (1983). A small volume, shortincubation-time method for measurement of photosynthesis as a function of incident irradiance. Mar. Ecol. Prog. Ser. 13: 99-102

Mallin, M. A., Paerl, H. W., Rudek, J. (1991). Seasonal phytoplankton composition, productivity, and biomass in the Nuese River estuary, North Carolina. Estuar. coast. Shelf Sci. 32: 609-623

Mitchell, B. G., Kiefer, D. A. (1984). Determination of absorption and fluorescence excitation spectra for phytoplankton. In. Holm-Hansen, O., Bolis, L, Gilles, R. (eds.) Marine phytoplankton and praductivity. Springer-Verlag, New York, p. $157-169$

This article was presented by T. Platt, Dartmouth, N.S., Canada
Paerl, H. W. (1988). Nuisance phytoplankton blooms in coastal, estuarine, and inland waters. Limnol. Oceanogr. 33 823-847

Pennock, J. R., Sharp, J. H. (1986). Phytoplankton production in the Delaware Estuary: temporal and spatial variability. Mar Ecol. Prog. Ser 34.143-155

Perry, M. J., Talbot, M. C., Alberte, R. S. (1981). Photoadaptation in marine phytoplankton: response of the photosynthetic unit. Mar Biol. 62: 91-101

Platt, T., Gallegos, C. L., Harrison, W. G. (1980). Photoinhibition of photosynthesis in natural assemblages of marine phytoplankton. J. Mar. Res. 38: 687-701

Platt, T., Sathyendranath, S. (1988). Oceanic primary production: estimation by remote sensing at local and regional scales. Science 241: 1613-1620

Prézelin, B. B. (1981). Light reactions in photosynthesis. In Platt, T (ed.) Physiological bases of phytoplankton ecology. Can. Bull. Fish. Aquat. Sci. 210: 1-43

Reynolds, C. S., Thompson, J. M., Ferguson, A. J. D., Wiseman, S. W. (1982). Loss processes in the population dynamics of phytoplankton maintained in closed systems. J. Plankton Res. 4: 561-600

Riley, G. A. (1967). The plankton of estuaries. In: Lauff, G. H (ed.) Estuaries. American Assoc. for the Advancement of Science, Washington, D.C., p. 316-326

Rivkin, R. B., Seliger, H. H. (1981). Liquid scintillation counting for ${ }^{14} \mathrm{C}$ uptake of single algal cells isolated from natural samples. Limnol. Oceanogr 26: 780-785

Ryther, J. H., Yentsch, C. S. (1957). The estimation of phytoplankton production in the ocean from chlorophyll and light data. Limnol. Oceanogr 2: 281-286

Sakshaug, E., Kiefer, D. A., Andresen, K. (1989). A steady state description of growth and light absorption in the marine planktonic diatom Skeletonema costatum. Limnol Oceanogr. 34: 188-197

Sathyendranath, S., Platt, $T$ (1989). Computation of aquatic primary production: extended formalism to include effect of angular and spectral distributions of light. Limnol. Oceanogr. 34: 188-197

Sephton, D. H., Harris, G. P. (1984). Physical variability and phytoplankton communities. VI. Day to day changes in primary productivity and species abundance. Arch Hydrobiol. 102: 155-175

Strathmann, R. R. (1967). Estimating the organic carbon content of phytoplankton from cell volume or plasma volume Limnol. Oceanogr 12: 411-418

Strickland, J. D. H., Parsons, T R. (1972). A practical handbook of seawater analysis, 2nd edn. Bull. Fish. Res. Bd Can. Ottawa

Takahashi, M., Parsons, T. R. (1972). The maximization of the standing stock and primary productivity of phytoplankton under natural conditions. Indian J. mar Sci. 1: 61-62

Manuscript first received. July 9, 1991

Revised version accepted: March 4, 1992 